\title{
Discourse and Representation in Emblematics: Hermeneutic and Ideological Implications of Stylistic and Cognitive Analyses
}

\author{
Daniele Borgogni \\ Department of Humanities, University of Turin, Italy
}

Copyright $(2019$ by authors, all rights reserved. Authors agree that this article remains permanently open access under the terms of the Creative Commons Attribution License 4.0 International License

\begin{abstract}
The article focuses on the dialectic relationship between visual and verbal representations in Renaissance emblematics, a multimodal genre in which words and images were inherently interactive and physiologically intermingled. Devices and emblems were "assemblages" of different modes and mediums, full of rhetorical wit and sophisticated allusions, and made the most of their appealing mix of discourse and representation to provide a practical moral lesson together with learned amusement. The article tries to discuss and revise these well-known aspects from a stylistic and cognitive perspective, relying on the analytical tools provided by Relevance Theory and Conceptual Integration Theory in the belief that such synergetic approach to emblematic texts is particularly rewarding to highlight the ideological implications of the unprecedented power attributed to the relation between images and language in the Renaissance. In particular, the article underscores the ideological dimension of emblematics, in a period rife with political and social tensions, and tries to draw attention to the ways in which this symbolic form of communication was transformed into an Althusserian practice of interpellation, interrogating the authority of the speaking subject and producing changing patterns in its relationship with the reader.
\end{abstract}

Keywords Emblematics, Image, Text, Ideology, Relevance Theory, Conceptual Integration Theory

\section{Introduction and Objectives}

This article $^{1}$ focuses on Renaissance emblematics and

1 A shorter, provisional version of this article was presented as a paper at the 38th Annual Conference of the Poetics and Linguistics Association, University of Birmingham (25-28 July 2018). will first discuss some features of this form and then will analyse some emblematic texts and their ideological bearings from a stylistic and cognitive perspective, mainly relying on the theoretical frameworks of Sperber and Wilson's Relevance Theory [1] and Fauconnier and Turner's Conceptual Integration Theory [2].

The symbolic genre of emblematics was an "archaeological" form of multimodal communication in which words and images were inherently interactive and physiologically intermingled, relying on different modes and mediums to entertain and educate the reader. Emblems often turned out to be ethical, political, and aesthetic "assemblages" which took advantage of an appealing mix of discourse and representation to provide a practical moral lesson together with a learned amusement, full of rhetorical wit and sophisticated allusions. For this reason, a stylistic and cognitive examination of the relations between images and words in emblematic texts may highlight some fundamental features that need to be more widely recognized, and some ideological implications of the unprecedented power attributed to the relation between images and language in the Renaissance.

\section{Methods}

\subsection{Relevance Theory and Emblematics}

Relevance Theory seems especially suitable to discuss some features of emblematics: one of the fundamental aspects for the interpretation and appreciation of devices and emblems, the centrality of the hermeneutic moment rather than the creative one (see also the following section "Results"), is in tune with the theoretical model of inferential communication proposed by Sperber - Wilson [1]. It involves the creation and evaluation of hypotheses about the communicator's intentions and, consequently, relies the reader's ability to infer a multitude of meanings 
by drawing implicatures from contextual assumptions and contextual implications. In particular, the very idea of contextual implication (a conclusion that can be inferred only from the joint consideration of input and context; see $\$ 2.7$ in Sperber - Wilson [1]) shares one of the central tenets of emblematics, namely the necessity of deriving interpretations from the interaction of all the elements of the composition.

Emblematists took it for granted that the texts they were producing (and the ideas they intended to convey) would trigger enough contextual effects to be worth the readers' special processing efforts. Even what we would consider communicative indeterminacy was in fact quintessential, because there was more to enjoying an emblem than just recovering its exact meaning and there was always an inherent gap between its semantic representations and the thoughts communicated. The pleasure of their interpretation lay in the inferential process of reconstruction of possible meanings triggered off by the interrelationship of motto, image and text.

This brought about new synthetic implications through the interaction between new and old information in the form of contextual implications. What made emblematics so peculiar, in other words, was not only the positive cognitive effects it produced, but also the fact that it required a special processing effort: while, according to Wilson - Sperber [3], "the greater the processing effort expended, the lower the relevance of the input to the individual" (p. 609), early emblematists were prodigal in providing as many weak implicatures as possible to stimulate the reader's own hermeneutic participation in the meaning production and thus satisfy their expectations of optimal relevance. $^{2}$

In other words, emblems and devices could only presume their optimal relevance because they were composed to produce a wide array of weak implicatures. The additional processing effort required of the reader and the emphasis on his hermeneutic ability to draw a series of contextual implications meant that readers were expected to walk along multiple interpretative paths, create additional contextual effects, and gain unpredictable cognitive effects.

\subsection{Conceptual Integration Theory and Emblematics}

Emblematics also provides exemplary case studies from the perspective of the Conceptual Integration Theory proposed by Fauconnier - Turner [2]: in fact, most emblematic texts stemmed from the dynamic blending of concepts and objects (see some examples in Figures 1-3) which were artificially integrated in a conceptual network

2 According to Wilson - Sperber [3], optimal relevance is achieved when an ostensive stimulus (i.e. a stimulus that is explicitly pointed at as relevant and that conveys the presumption of its own optimal relevance) is relevant enough to be worth the audience's processing effort and it is the most relevant one compatible with the writer's abilities and preferences. to produce new meanings. The mental operations triggered by most emblematic texts can be set within the skeletal construct of the generic space of early modern epistemology, which took the coherence and the structure of the analogies for granted; then, the cross-space mappings and interactions between domains selectively projected stimuli into the blended space of the composition, thereby producing new, emergent meanings.

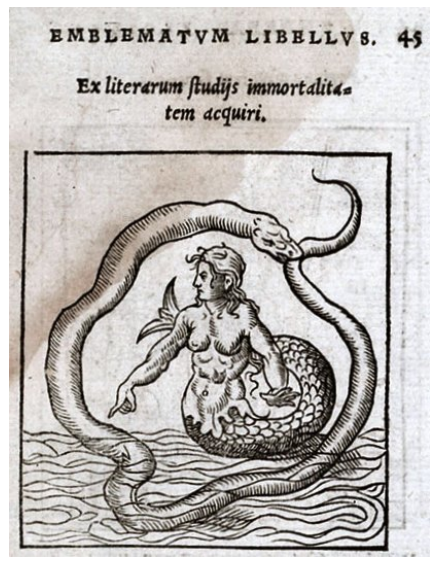

Figure 1. From Alciato [45]

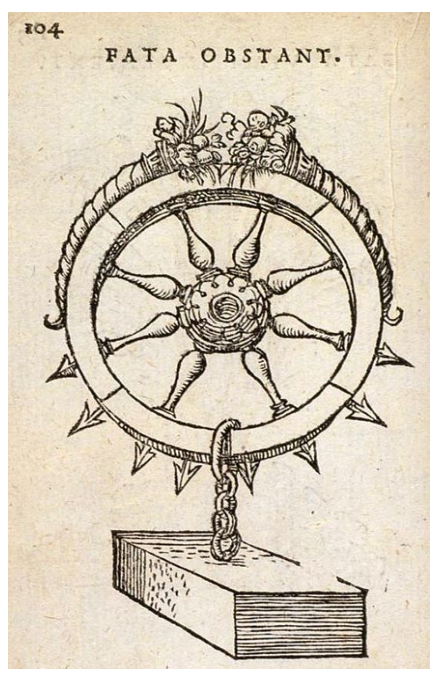

Figure 2. From Paradin [48]

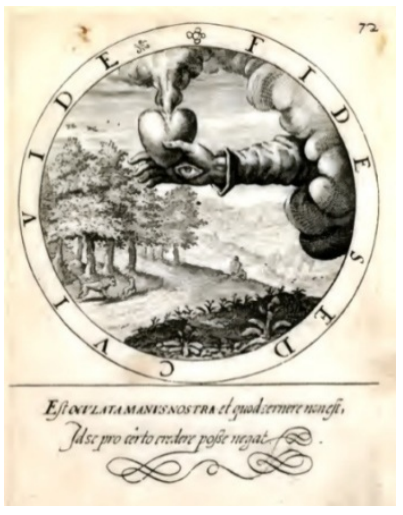

Figure 3. From Rollenhagen [49] 
As Grady - Oakley - Coulson [4] point out, the functional interaction between domains is the consequence of a threefold process: composition (i.e., the projection and fusion of selected elements from the input spaces into the blended space through selectivity and compression); completion (i.e., the introduction of supplementary notions we normally associate with the projected elements and that allow us to complete the scenario); and elaboration (i.e., the "simulated mental performance of the event in the blend, which we may continue indefinitely" and through which we "are able to imagine scenarios which unfold along various possible trajectories" (p. 107).

The importance of composition, completion and elaboration cannot be overestimated, because their interaction makes the same message interpretable in very different ways: as Fludernik [5] contends, "proliferations of meaning arising from the source domain are in fact unlimited" (p. 11), because it multiplies the hermeneutic possibilities that can be established between the various spaces. This also sheds light on the characteristically ideological role of emblematics, especially in its didactic use, since, as Dancygier [6] put it, a mental space "is an ad hoc mental structure allowing for some understanding of a situation, then it is naturally also a locus of viewpoint" ( $p$. 111).

The cognitive perspective of Conceptual Integration Theory is particularly relevant for the study of emblematics also because it confirms the importance of empathy in experiencing art works: in their article on the emotional response to aesthetic experience (see also Currie [7] on this topic), Freedberg - Gallese [8] demonstrated that mirror neurons are activated both when we act and when we observe the same action performed by someone else, thus "mirroring" others' behaviors as if we ourselves were acting or feeling. In this way, the movements and emotions represented in a work of art stimulate a neural response in the beholder which produces a sense of physical involvement. This process of embodied simulation "enables the direct experiential understanding of the intentional and emotional contents of images" ( $p$. 202), because the neural circuits activated in one's brain are exactly those which would be activated if one performed the actions shown in that image.

Embodied simulation was of paramount importance in emblematic texts, because the interaction of words and images could elicit from the reader an identification process and therefore an intense emotional response and the stimulated by the various elements of the composition helped move, delight and teach in an undeniably strong way. In particular, the inherently didactic nature of emblems (as opposed to the more intuitive and enigmatic nature of devices) meant that emblem writers always aimed at transmitting concrete, applied knowledge to everyday life, thus producing literary entertainment as well as indirectly highlighting their own usefulness.

\section{Results}

\subsection{Emblematics and Multimediality}

Emblematics was a versatile form of communication which developed from ancient and medieval symbolic forms and sources, from classical mythology to history, from natural phenomena to popular lore (on such "commonplaces" see Moss [9]). Its appealing mix of verbal and iconographic elements made it ubiquitous in early modern European culture because it seemed to provide the perfect answer to the epistemic dream of giving material expression to abstract concepts: as Bacon [10] wrote, the "Emblem reduceth conceits intellectual to images sensible, which strike the memory more" (p. 130).

Whereas traditionally poetry had been separated from the image, in an emblematic text they were united (and usually referred to as the soul and the body) and early modern scholars cherished the association of painting and poetry to achieve a desirable fusion of physical objects and mental concepts, because it made it possible to conceive the idea of understanding with the senses or feeling with the intellect: describing the written and visual parts, Marino [11] maintained that "Somigliansi tanto queste due care gemelle nate d'un parto [...] La Poesia è detta pittura parlante, la pittura poesia taciturna; [...] L'una fà quasi intendere co' sensi, l'altra sentire con l'intelletto" ["These two sweet twins born of one birth are so alike [...] Poetry is said to be a speaking picture, picture a silent poem; [...] the one almost lets one understand through the senses, the other hear through the intellect"] (pp. 71-72).

Emblems and devices were thus liminal compositions straddling two semiotic systems (linguistic and figural) and inherently involved in the early modern debate on the relationships between nature and representation, art and language (on this see the classic studies by Hagstrum [12], Clements [13] and Lee [14]). Of course, emblems and devices were basically what Elkins [15] termed "informational images", but their non-artistic status is just what allows the analysis of the peculiar relationship between these images and pictorial conventions. As Elkins explains, non-artistic images feature a special complexity because their referential quality is typically unstable, since they impose on the reader peculiar hermeneutic practices which must take into account the relation between pictorial and linguistic signs.

Traditionally, emblematics was dismissed as an erudite pastime for antiquarians, or a sort of old curiosity shop to expose the Renaissance symbolic frame of mind; yet, emblematic texts were multimedial objects, "iconotexts" as Louvel [16] calls them, on which words and images converged and mixed to produce a brand-new form while keeping their own prerogatives and thus provide a useful intellectual atlas to investigate some aspects of early modern culture. To use Mitchell's terminology [17], devices and emblems turned out to be "discursive hypericons" or "talking metapictures", because they 
offered "a representation of the relation between discourse and representation, a picture about the gap between words and pictures" (p. 65).

It must be equally stressed, however, that a comparative formalistic approach can highlight the relation between texts and images but must not cancel the equally fundamental tenet that images have their own grammar and must be read and interpreted iuxta propria principia. Mitchell himself [18] exposes the limits of a totalizing approach and the "hope for some master trope" (p. 157), and Rodowick [19] rightly reminds that the limit of the structuralist approach was "the inability to comprehend the problem of meaning as other than linguistic" (p. 4)

In emblematic texts, the unique tie between verbal and visual elements questioned the traditional idea that the lack of eloquence inherent in figures meant that, to be meaningful, they must be surrounded and supported by linguistic statements. On the contrary, the involvement of the readers in the production of meanings prevented them from getting a simple, straightforward interpretation, Thus, more than other expressive forms, emblematics lay at the very heart of the early modern anxieties and doubts about language and its ability to be tied to things, events, and actions, because it invested the relation between "verbalization" and "spatialization", between what was seen and what could be said about it.

\subsection{Emblematics and Reader Response}

From a structural point of view (but with a lot of conspicuous exceptions), emblematic texts usually featured a motto (or inscriptio) and a symbolic image (pictura); in the case of emblems, there was also an accompanying text (subscriptio). These elements had special relevance not in themselves but in their mutual analogic interactions. ${ }^{3}$ The semiotic interdependence between visual and verbal elements was not perceived as redundancy but the precondition of a transparent, immediate form of communication. In short, despite its composite nature, its great variety of topics (from politics to religion, from love to moral issues) and forms (from the more esoteric and intellectual devices to the more popular emblems), emblematics was considered a simple, essential form, which allowed the reader to perceive intuitively the intellectual unity underlying the material plurality. It is not surprising, therefore, that emblematics acquired a new philosophical and cognitive dimension: it was valued for its ability to open up new cognitive possibilities as a pure form of intuitive knowledge akin to the divine, for producing

\footnotetext{
3 Even if for some critics there is a basic arbitrariness in the coupling of the motto and the image, the interdependence between the written and the visual parts was considered an inherent characteristic of emblematics in early theoretical studies such as Giovio's [20]. As Colie [21] put it: "No part of the emblem - figure, epigram, caption, or adage - was supposed to translate any other: rather all the elements were by their special means to point inward to a single idea, supported in part by all of them" (p. 37).
}

symbolic meanings, and for revealing hidden correspondences among things (on this topic see the classic studies by Praz [22], Gombrich [23], Henkel - Schöne [24]).

Of course, as Visser [25] rightly stresses, the relationship between verbal and visual elements was highly flexible "ranging from a connection in which one part illustrates the other to more dynamic forms of interaction" (p. xxv), but it was significant because, especially at the beginning, devices and emblems were not conceived as 'readable' but 'writable' texts: the materiality of the sign was not devalued as a mere sensible element to be transcended in order to get at the real, spiritual meaning: as Spica [26] stressed, 'L'emblème constitue le lieu où l'on matérialise l'insertion de l'image dans le texte, où l'on a rendu l'image porteuse de vérité" (p. 247) ["the emblem is the place where the insertion of the image within the text takes shape, where the image was made the bearer of truth"].

An emblematic composition did not possess a single, immediately perceptible meaning and its richness was to be discovered progressively in a sort of mystic contemplation in which the various parts mutually explained one another and conveyed a wide array of implications. From this point of view, emblems and devices were an early demonstration of Boehm's [27] concept of "intermediality", the fact that media never come alone but they always exist as mixed media, mutually quoting and overlapping.

Moreover, they soon achieved a privileged position as a form of expression, because they could exploit the strengths of both poetry and painting, and multiply the range of possible interpretations, thus placing emblematics at the heart of the early modern debate on art and nature, and seemingly offering the solution to the old conflict between showing and telling which had been featuring prominently in rhetorical treatises since Cicero and Quintilian.

Emblematics is, thus, particularly interesting because thanks to its amphibious, mongrel nature was able to radically displace and reconceptualize the relationship between words and things and, by reuniting within a single work of art signification and expression, sanctioned the possibility of considering the figural and the verbal not as mutually exclusive, but as usefully collaborative dimensions. From this perspective, emblematic discourse can be redefined in Rodowick's [19] words "not as the hierarchy of one to the other, but as the heterogeneous space of their cohabitation" (p. 8).

\subsection{Emblematics and Entextualization}

Emblematics also featured a peculiar type of textual fragmentation, especially evident in the many cases of reutilization of engravings (on this aspect see, among others, Praz [22], Henkel - Schöne [24], Adams -Rawles Saunders [28]. This common practice was of course an 
economic necessity, but confirms that fact that an image could be used in many ways and its various elements might acquire a relevance that was not present in the original image. This phenomenon is what linguistic anthropology calls "entextualization" (see Gal [29]), the idea, as Keane [30] explains, that "chunks of discourse come to be extractable from particular contexts and thereby made portable. [...] These chunks of discourse, or 'texts' can thereby circulate and be recontextualized, inserted into new contexts" (p. 14). As a matter of fact, as Russell [31] clarifies, in France the emblem "was apparently considered to be some sort of detachable and perhaps borrowed rhetorical ornament. It could be either the text $[\ldots]$ or it could be the detachable ornamental illustration of the text" (p. 341). Similarly, Spica [32] maintains that emblems and devices were a "série de petites totalités closes qui font du livre une collection de fragments" (p. 170), because they consisted of a series of malleable, interchangeable units which could become the constituents of a new grammar arranged in a new syntax (on this aspect see the short but very interesting remarks by Roukhomovsky [33]). In an emblematic composition, therefore, texts were fluidly spatialized and spaces were 'textualized', losing their uniform contours, fixed spacing, and linear sense. As Rodowick [19] wrote of postmodern visual forms, "suddenly the image was becoming articulable, indeed discursive, like never before" (p. 3).

The possibility of entextualization demonstrates that, contrary to what is usually believed, emblematics did not convey a closed vision of reality in which objects and concepts had a fixed and necessary relationship. Emblematic texts relied on the inseparableness of form and content, but at the same time they exploited the possibility of separating contents from their original forms, thereby creating new relations, motivated but not necessary. As a consequence, the reader was given the possibility of multiplying his reading possibilities and creating new meanings through his hermeneutic act.

The process of entextualization in emblematic texts was, thus, doubly ideological, because it not only implied the selection of texts and images and their recombination into a new whole, but it also claimed that the new text was superior because it featured a necessary union between words and images. Even devices, inherently personal and invested with the intent of the individual bearer, underwent the same process, as a quick look to such encyclopedic works as Picinelli [34], with its full repertoire of mottos and images, confirms.

More than this, in emblematic texts, words and images could convey different meanings and purposes when placed in a new context, but they could also retain their original associations with former contexts, thus opening up virtually inexhaustible semiotic possibilities: texts, objects, and images could mean something and something else at the same time; the single emblematic text could rely on a symbolic reading and a literal reading at the same time; signifiers and signified could be presented as mutually independent and inextricably tied at the same time.

This means that emblematics also questioned the traditional practice of simply equating showing with images and telling with texts: modern literary texts and contemporary literary theory have amply demonstrated that the mimetic quality of "showing" can be associated to dialogue as well as "telling" (on this see Engelberts [35]). And starting from the XV century, with the invention of the printing press and its ensuing mechanization processes, verbal descriptions did not lose their importance but "pictorial" representations soon acquired momentum, becoming more frequent and much more widely available. Showing things, in other words, could be associated both to writing and to painting, both to images and to words.

Emblematics was, then, ahead of its times in the way it faced a typically modern problem: on the one side, artists were often compelled to assimilate pictures to texts, thus overlooking or attenuating the former's peculiar visual nature; on the other, writers experienced the reverse difficulty of conforming text to pictures, thus overlooking or attenuating their peculiar written strangeness. In emblematics, on the contrary, the association of showing to both words and images allowed the proliferation of hidden, elusive meanings, which could find their fulfilment only in the reader's imagination and hermeneutic effort. After all, emblematic texts did not aim at disambiguation and clarification; rather, they were artistic constructs which repeatedly invited the reader to go beyond and accept the fact that the mere verbal aspect or the mere visual element could not be taken at their face value but should be synergetically put together to foster the reader's negotiation with signification. Emblematic texts had their own creative powers and made polyvalent semiotic objects, and their infinite meaning potentialities could be actualized only by the reader's hermeneutic abilities: as Fumaroli [36] maintains, the reader was expected to "percevoir, dans les anfractuosités des brefs membra [...], ce "je ne sais quoi" que l'écrivain lui désigne sans pouvoir ni vouloir le justifier" (p. 61) [perceive, within the anfractuosities of the short membra ... that "je ne sais quoi" which the writer alludes to without being able, or willing, to justify].

\subsection{Emblematics and Ideology}

The portability of specific textual elements featured prominently in emblematics and gave it a typical ideological affiliation. As Visser [25] explains, "the emblem was a highly flexible, multi-purpose form, which could equally well serve patronage relations, scholarly friendship as didactic contexts" (p. xvii) (for a practical application of these ideas, albeit in a different context, see Leone [37]). As a matter of fact, due to their costs, emblem books were not particularly profitable to publishers and authors, so the genre came to be used to suit the most diverse needs, from self-fashioning to patron flattery, from maintaining friendly relationships to claiming class 
affiliation, from building one's reputation to providing religious education, from reinforcing moral values to imposing social behaviors.

Thus, emblematic texts became "culturalized" expressive forms, increasingly related to early modern practices of construction and representation of the self. Emblems, in particular, were increasingly exploited for religious and moral purposes, with extensive moralizations deliberately seasoned with learned intertextual relations to make them more palatable, according to the Aristotelian and Horatian ideal of mixing usefulness and delight. As Keane [30] aptly explains "At the conceptual core of the scriptural religions are the products of entextualization, texts extracted from one context that can have powerful effects when recontextualized in another: scriptures, creeds, catechisms, liturgies, sermons, prayers, hymns, and so forth" (p. 211).

A good example in case is the highly polytropic image of the ostrich (see Borgogni [38]), a clear example of how in emblematics words and objects were liable to what Keane [30] described as the "appropriation in new contexts [...] shifting in their relative utility and significance, serving new purposes. The power of speech [...] plays its roles in different representational economies and gives rise to different modes of objectification" (p. 269).

\subsection{Emblematics and Corporealized Vision}

The bimedial nature of emblematics and its ideological affiliations had also a fundamental, though paradoxical, effect as to its reading modalities. Emblematics entailed an active interpretation of the various elements inserted in a composition, but at the same time authors were at pains to ensure and impose the correct, orthodox understanding of the symbols they proposed. ${ }^{4}$ Emblematic texts were thus refractive as well as reflective, requiring an active and at the same time passive role of the reader, epitomizing what Mitchell [17] defined "the tendency of the technologies of visual representation to acquire a figurative centrality in theories of the self and its knowledges" because it produced "aesthetic 'assemblages' that allow us to observe observers" (p. 49) and understand something of their constructedness. ${ }^{5}$

4 Of course, the hermeneutic moment was the most delicate and problematic aspect in any emblematic composition, and things were not always so straightforward and linear as the above words might seem to imply; on this see Pinkus [39] and basically all the Italian theoretical writings collected in Barocchi [40].

5 Moreover, the material aspects of the consumption of an emblematic text implied an embodied optics of bodies and pleasures: as many postmodern thinkers have contended, in the relationship between words and images the latter can be associated to an economy of desire (as maintained by Lyotard) producing a sort of return of the repressed (as Mitchell stresses). Of course, postmodern thinkers such as Foucault Lyotard, Mitchell, or Rodowick discuss all these aspects in relation to their analysis of the pictorial turn in postmodern times, but their insights are extremely important for a period and a form of art which realized the necessity to investigate the relation of images to words to answer its most profound epistemological anxieties.
It is worth remembering that this paradoxical nature of emblematic texts can be best appreciated if we remember that they were not transparent windows onto an objective world of separate objects (though undoubtedly exploiting the referentiality of words and images), nor were they blinding, self-consuming artifacts simply stimulating the reader to transcend and go beyond their materiality (although Neoplatonic ideas of silenic truths achievable through pure intuition was one of its main tenets). The material visuality and material aesthetic in emblematics was one of its signature features but still needs to be recognized and discussed properly. Emblematics favored a multisensorial model of consumption, in which mental images could find a concrete, physical embodiment, thereby strengthening the overlap between the intellectual pleasure of intuiting and pursuing mental ideas, and the bodily experience of physically see and touch delightful objects.

This means that emblematics was not the carrier of a meaning generated elsewhere and perceived by the disembodied gaze of the viewer; on the contrary, it was characterized by a multisensorial nature which bolstered what Crary [41] termed "corporeality of vision" (p. 141): the reader was expected to enjoy the symbolic meanings of the text, but at the same time he was placed at the center of a transformation process which involved his whole life and body. ${ }^{6}$

In short, since hermeneutic aspects, personal aspirations, political issues and religious norms blurred and overlapped, merging the public and the private sphere, the practices of vision that emblematics imposed were always imbricated in a phenomenological, multi-sensorial world of desires and affects. The composite nature of emblems meant that the experience of reading them was never just visual, but also tactile, fully embodied, and affected by the material properties of the objects. Meanings, memories and fantasies could be engendered and given both cultural and emotional values, so they were used to create or reinforce individual and social identities and norms. Emblematics always dislocated the here and now of the actual reader displacing it into an imaginative there and then, producing a sort of hallucinatory experience which ultimately aimed at manipulating and "re-creating" the reader himself, favoring the process of his reification and interpellation as subject.

To consider emblems as archeologic forms of a new articulation of 'corporealized vision' opens up interesting new perspectives for their interpretation, because it means to analyze the material exchanges and relays between physical and mental objects. The materiality of emblem or

6 Readers undoubtedly had to comply with specific rules and codes, but this does not necessarily confirm Crary's idea that before the XIX century the nature of vision was decorporealized and dualist, based on stable relations between outside reality and the autonomous rational inner vision of a free viewing subject (see Crary [41], esp. pp. 25-66). 
device collections made them visual representations in the form of material memories and teachings, thus connecting the act of reading with the material existence of the reader. As already stressed in the preceding section, the shaping of books, their artistic quality, their layout and margins, all conveyed an ideological surplus to the experience of reading, which was particularly evident in emblematic texts. At the same time, the high cost and increasing refinement of emblem books, the multisensorial pleasures they allowed thanks to their union of words and images, meant that they circulated as gifts and tokens of exchange thus reinforcing the link between cultural and ideological issues.

For this reason, emblematics cannot be reductively studied as a quaint, self-pleasing exercise or as a repository of literary motifs or iconographical topoi; it is in fact a rather more complex form, a wide cultural index which can provide a privileged perspective on the most problematic aspects of early modern culture: the relation between texts, images and ideology, or the problematic nature of philosophical (epistemological), pictorial, social (political), even ethical representations in a period rife with political, religious, and social tensions connected to the construction of the body and language.

\section{Discussion}

\subsection{A Relevance Theoretic Reading of Palmer's Emblem 61}

The first English emblem book, Palmer's Two Hundred Poosees (1566), ${ }^{7}$ is a good example of the early "hieroglyphic" emblematics which seemed to defy the idea of optimal relevance. Emblem 61 features an evident dyscrasia between the motto ("Againste lovers and harlottes") and the pictura, which is taken from the Paris edition of Alciato's emblems [45] and shows a fisher along a river wearing a goatskin with a big fish lying on his net (see Figure 4).

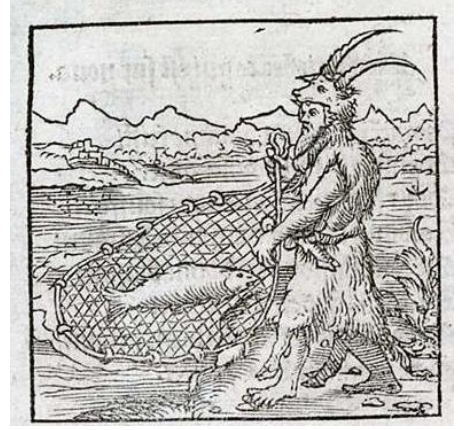

Figure 4. From Alciato [45]

7 For further information on Palmer's volume see Manning [42], Manning [43], and Bath [44]. The only available edition of this collection of emblems is the transcription provided by Manning [43].
On the whole, the image is rather puzzling and the subscriptio, too, is far from providing satisfactory information (Manning [43], p. 66):

\section{Againste lovers and harlottes.}

The goates caste on the seae their shade, by fedinge on the sande:

For ioye whereof Sargus the fishe

leps vp, and drawes to lande.

The fissher ware of this, takes from 5 the goate his gainfull skyn:

And makes a shadowe for his bayte, this folishe fishe to wyn.

This fishe vnto a lover maye

by reason be comparde:

The goates these harlottes fals and faire me thinkes have well declarde.

Whose shadowde shape and fleringe face alluringe youthe to yll,

Sendes theim into the nette of those, 15 that seke to spoile and spill.

The text refers to little known and thus rather costly ${ }^{8}$ Classical sources: as Oppian's poem on fishing Halieutica (IV, 308-373) and Aelian's De natura animalium (I.23) maintained, it was commonly believed that breams were so irresistibly attracted by goats that they jumped out of the water to touch them, and fishermen could easily capture them by dressing up as goats. The reader gets to know that the animal is not just any fish but a sargus (possibly the sea-bream, in any case a costly reference), but on the whole the description of its strange behavior does not seem to convey any clear relevant contextual effect. Also, the term "gainfull" (line 6) is rather costly, since it is used not so much as an objective attribute of the goatskin, but to convey the subjective perspective of the fisherman's profit.

Moreover, the reader has to wait till line 9 to start understanding the moral application of the text, even though the comparison "by reason" (line 10) between the fish and a lover is quite arbitrary: moreover, the traditional theme of deceitful appearance is not referred to harlots' beguiling appearances: in contrast with the expectation raised by lines 11-12, the emblem does not show a disguised harlot, but a disguised fisherman, that is a fisherman disguised as a goat which was traditionally associated to sexual incontinence.

Finally, it turns out the concluding warning is not against

8 This "cost" refers of course to the hermeneutic effort that is required from the reader: Wilson - Sperber [46] stress the importance of processing effort in utterance interpretation: "By demanding extra processing effort for example, by answering a question indirectly - the speaker can encourage the hearer to look for additional contextual effects in the form of additional weak or strong implicatures" (p. 99). This is apparently a hindrance to the achieving of optimal relevance, since it does not favor communication and interpretation but imposes a pressure on the reader who then expects an extra meaning and relevance that justify the supplementary effort. 
"lovers and harlottes" as the title suggests, but some unmentioned "those" (line 15) who can take advantage of people's passions: the closing remark, thus, seems a totally arbitrary conclusion only tenuously linked to the description presented in the subscriptio.

The unexpected connections between the title, the image, and the text oblige the reader to stop several times while reading, make different hypotheses and possibly change his expectations. So, the overall impression is that the meaning of the emblem is almost suspended; at the same time, the series of weak implicatures which open up alternative interpretations suggest that the whole composition does not aim at imposing a single, correct interpretation, but at providing a series of elements and meanings that is up to the reader to pursue or drop.

To sum up, for for an early emblematist like Palmer the fundamental idea was that there might be potentially infinite "revelations" and even ambiguous cross references in a composition. The expectation was that the cognitive effects were well worth any processing effort, because the pleasure lay exactly in the hermeneutic building of possible readings pursuing the potential contextual assumptions in the form of implicated premises to achieve a certain range of contextual implications as implicated conclusions. This meant that emblematists were of course pursuing optimal relevance, but they were deeply reliant on the active response of the reader to go after and appreciate the many weak implicatures of their works and, consequently, unleash the whole array of contextual effects. ${ }^{9}$

\subsection{Interpellating Tongues: Blending and Ideology in Three Emblematic Texts}

Paradin's device Quo tendis? in its 1551 original edition (Paradin [48], p. 62), was the mere combination of woodcut figure and motto (see Figure 5), and as such it was the model for Rollenhagen's emblem 42 (Rollenhagen [49]) (see Figure 6), whose short subscriptio was just a general invitation to learn to shut up: "Garrula, quo tendis? Quo te furor impia lingua / Abripit? Ah presso, disce tacere, labro" (p. 42) [Garrulous, where do you aim at? Where does frenzy pull you to, impious tongue? / Ah, learn to hush with your lips buttoned].

9 The text imposes a kind fruition that seems to defy the more straightforward model of communication envisioned by pragmatists: seen from the perspective of Grice [47], for instance, the text would feature a blatant flouting of several of his maxims and sub-maxims of conversation: Quantity (the writer is certainly not as informative as is required for the current purposes of the exchange, since both the image and the text provide a lot of information that is not explained and left open to the reader's speculation); Relation (not all the elements presented in the emblem interact with the reader's existing assumptions about the world, hence the impression of an expense of multifarious inputs); Manner (if the text is arguably brief and orderly, it also fosters ambiguity, and does not avoid obscure expressions, as we have just seen), and even from a relevance theoretic perspective these flouts would imply a significant loss in relevance if the deliberate increase in processing effort were not offset by an increase in implicatures.

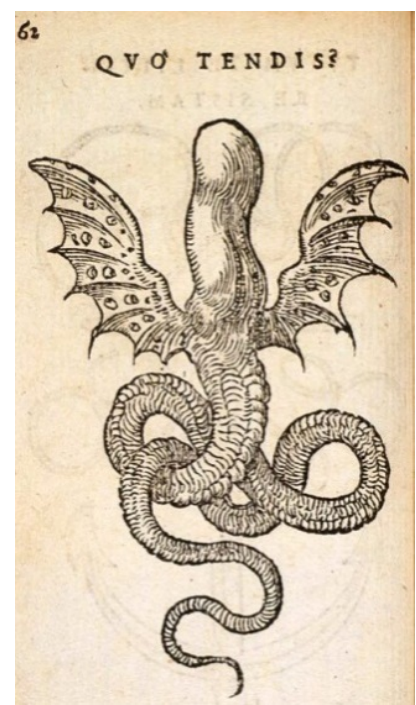

Figure 5. From Paradin [48]

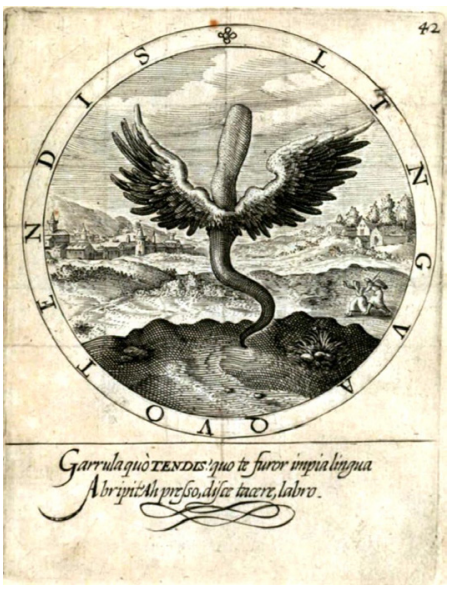

Figure 6. From Rollenhagen [49]

Significantly, in Paradin's 1557 edition (Paradin [50], pp. 109-10) (see figure 7), short prose commentaries were added to explain the significance of each device, the person who used it, its sources, and so on. As a consequence, the device was given a universally applicable moral lesson and the nature of the work changed dramatically. In this new form, each device was far more informative and overtly 'educational'. 


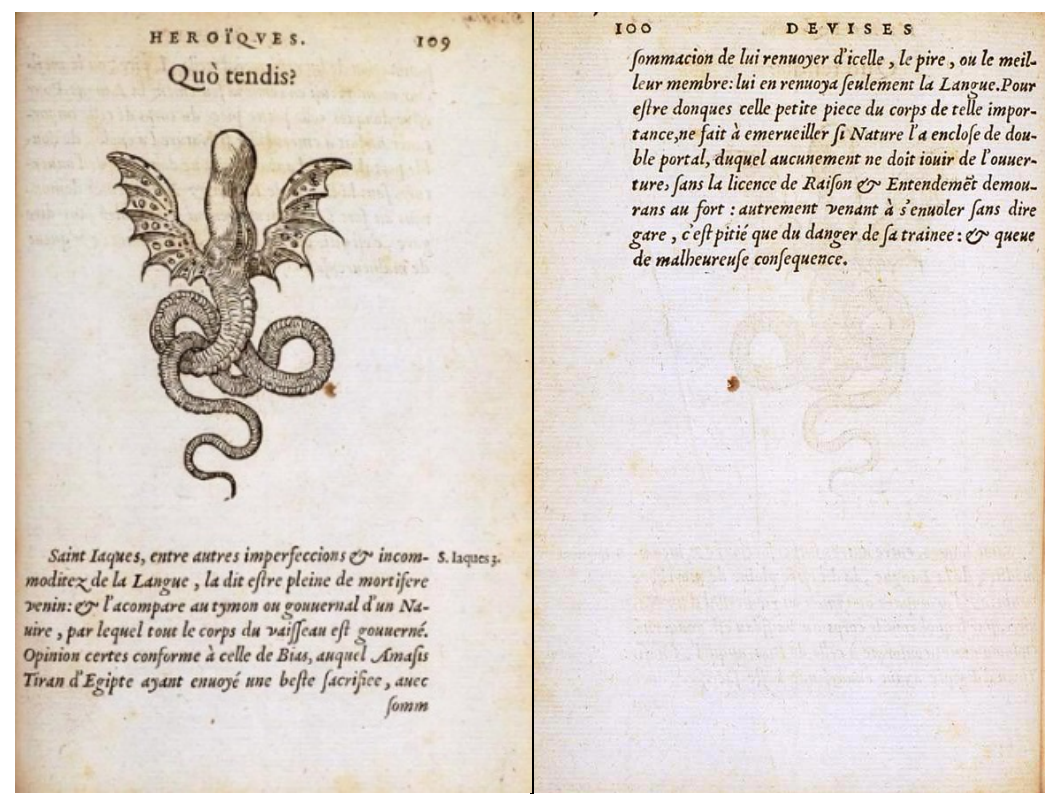

Figure 7. From Paradin [50]

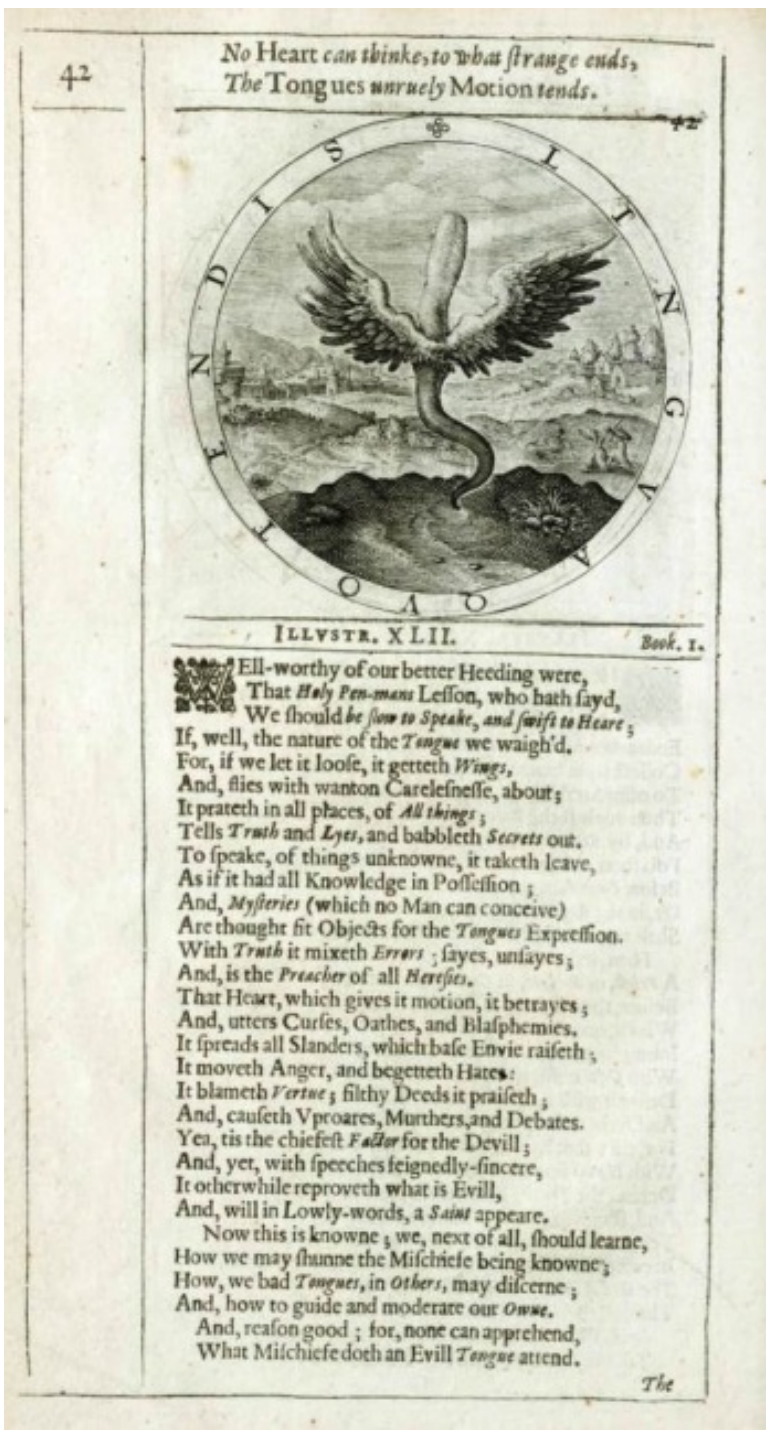

Figure 8. From Wither [51] 
Almost eighty years later, Wither's emblem 42 (Wither [51]; see Figure 8), imposed a similar reading dynamics: the warning is explicit, and there is no straying from the central message of the composition. Even the Latin motto is paraphrased to guide the reader towards a clearly moralistic interpretation (No Heart can thinke, to what strange end, / The Tongues unruely Motion tends, p. 42).

The verbose subscriptio revolves around a longish list of threats and sins that can be brought about by a careless tongue, possibly a reference to the contemporary political and epistemological tensions between the monarchy and the Parliament. As a consequence, the text does not open up different reading possibilities for the reader, nor is he stimulated to actively take part in the hermeneutic process, but just to be overwhelmed by the awe-inspiring comments of the monologic voice, who transforms them into moral allegories of spiritual truth. Moreover, the message is linked to age-old moral commonplaces à la Polonius, thus strengthening traditional assumptions and values:

Well worthy of our better Heeding were,

That Holy Pen-mans Lesson, who hath sayd, We should be slow to Speake, and swift to Heare;

If, well, the nature of the Tongue we waigh'd.

For, if we let it loose, it getteth Wings,

And, flies with wanton Carelessnesse about;

It prateth in all places, of All things;

Tells Truth and Lyes, and babbleth Secrets out.

To speake, of things unknowne, it taketh leave,

As if it had all Knowledge in Possession; 10

And, Mysteries (which no Man can conceive)

Are thought fit Objects for the Tongues Expression.

With Truth it mixeth Errors; says, unsayes;

And, is the Preacher of all Heresies.

That Heart, which gives it motion, it betrayes;

And, utters Curses, Oathes, and Blasphemies.

It spreads all Slanders, which base Envie raiseth;

It moveth Anger, and begetteth Hates:

It blameth Vertue; filthy Deeds it praiseth;

And, causeth Vproares, Murthers, and Debates.

Yea, tis the chiefest Factor for the Devill;

And, yet, with speeches feignedly-sincere,

It otherwhile reproveth what is Evill,

And, will in Lowly-words, a Saint appeare.

Now this is knowne; we next of all, should learne,

How we may shunne the Mischiefe being knowne;

How, we bad Tongues, in Others, may discerne;

And, how to guide and moderate our Owne.

And, reason good; for, none can apprehend,

What Mischiefe doth an Evill Tongue attend.

In terms of Relevance theory, optimal relevance is assured here because there is only one possible interpretation that must come to mind, the first and only one that all the various parts of the emblem focus on. This later and more didactic kind of emblem aimed at conveying only one fundamental message, whose ostensive stimulus was considered the most relevant one that the writer wanted and was able to produce. Readers were induced to follow the path of least effort and limit their hermeneutic effort to recover the one intended meaning, so the typical comprehension process of constructing hypotheses about explicatures and implicatures was clearly discouraged.

But there is more to this emblem than just the attempt to secure the right interpretation of symbols and figures: when analysed from the perspective of Conceptual Integration Theory, the emblem turns out to be built on a blending which exposes a clear Althusserian practice of interpellation. The blended space of the image is the consequence of the projection of selected elements from several input spaces (the human body, the bird, the snake, and other hellish animals represented by the serpentine form of the tongue, clearly evident in Paradin's image with dragon wings and scaly body). They reinforce the ideological bearing on the reader by reminding him the fundamentally sinful nature of his body: in particular, the winged serpentine tongue does not only underscore the common dangers inherent in words (gossiping or using inappropriate words), but it becomes a visible symbol of the deadly forces (and passions) that hide within man: in Paradin [49] what goes out of the mouth is "dangerous, and menace to man's salvation, "the chiefest Factor for the Devill" (line 21).

The metaphorical blend of the winged tongue is transformed into a multiple blend (i.e. a blend in which "either several inputs are projected in parallel, or they are projected successively into intermediate blends, which themselves serve as further inputs to further blends"; Fauconnier - Turner [2] p. 279) by the insertion of another input (the damnation space), so that the warning of the reader is metaphorically configured as a compression of elements (a winged tongue) which are then inserted into the image schema of downward movement (the moral dangers of an uncontrolled tongue which ultimately imply sin and damnation). This not only highlights the experiential structure of the blend, but clearly alludes to the condemnation of the tongue by exploiting the traditional connotation of its serpent-shaped form. The negative implicatures of these allusions are confirmed by the asymmetric topicality of the blend: only one of the inputs is topical while the other allows the re-framing of the first fo communicative purposes (this means that the tongue is the actual focus and the blend is interested in conceptualizing or describing some specific aspects of the tongue, not in understanding more about wings).

The necessity of a radical, thorough control of the reader's tongue is explicitly underscored in lines $25-28$. As a consequence, the annihilation and transformation of the reader's whole life and body is implied as a pressing, inescapable necessity. The thorough description and the pervasive guidance of the reader impose a univocal, immediately accessible interpretation that prevents him from processing the text in a different way; at the same 
time. The presentation of a detached piece of human body endowed with negative connotations demonstrates how the material aspect of the emblem was fundamental to trigger an experiential response and stimulate the identification of the reader with a part of his body, as in the embodied simulation process described by Freedberg - Gallese [8]: "The process of embodied simulation $[\ldots]$ enables the direct experiential understanding of the intentional and emotional contents of images. This basic level of reaction to images becomes essential to any understanding of their effectiveness as art. Historical and cultural or contextual factors do not contradict the importance of considering the neural processes that arise in the empathetic understanding of visual works of art" (p. 202).

In this way, the reader is the focus of an interpellation practice that surreptitiously aims at moulding him into an obedient subject, just like the reader has to transform his tongue into an obedient organ. After all, as the subscriptio repeatedly makes clear, the consequences of an uncontrolled use of the tongue concern all the body and can ultimately provoke its perpetual damnation.

\section{Conclusions}

In a period rife with political and social tensions, the flexibility of emblematics was often exploited to deviously transform the inadvertent reader into a pliant, submissive subjectus. In the case of Paradin's and Wither's texts, the image of the winged, serpent-shaped tongue ends up being a metonymy of an inherently flawed human body that needs careful checking, if not complete reformation.

This analysis demonstrates that a stylistic and cognitive approach to an apparently old and trivial form of multimediality like emblematics sheds light on the unprecedented power attributed to the relation between images and language in the early modern period and on their cultural and ideological bearings on the reader. The progressive passage from lesser to more constraining texts, or from more inferential to more coded forms of communication had not only hermeneutic consequences, but transformed emblematics into a privileged form to interpellate readers, stimulating their response to both create and self-impose a certain meaning, paradoxically making them at the same time producers and targets of that message.

\section{REFERENCES}

[1] D. Sperber, D. Wilson. Relevance. Communication and Cognition, $2^{\text {nd }}$ ed., Blackwell, Oxford 1995.

[2] G. Fauconnier, M. Turner. The Way We Think, Basic Books, New York, 2002.
[3] D. Wilson, D. Sperber. Relevance Theory, in L.R. Horn, G. Ward (eds.). The Handbook of Pragmatics, Blackwell, Oxford, 607-632, 2004.

[4] J. Grady, T. Oakley, S. Coulson. Blending and metaphor, in R.W. Gibbs, Jr. and G. Steen (eds.), Metaphor in cognitive linguistics, John Benjamins, Amsterdam and Philadelphia, 100-124, 1999.

[5] M. Fludernik. Naturalizing the unnatural: A view from blending theory, Journal of Literary Semantics Vol. 39, 1-27, 2010 .

[6] B. Dancygier. Blending and narrative viewpoint: Jonathan Raban's travels through mental spaces, Language and Literature Vol. 14, n. 2, 99-127, 2005.

[7] G. Currie, M. Kieran, A. Meskin, J. Robson (eds.). Aesthetics and the Sciences of Mind, Oxford University Press, Oxford, 2014.

[8] D. Freedberg, V. Gallese. Empathy, motion, emotion in aesthetic experience, Trends in Cognitive Sciences, Vol. 11, n. 5, 197-203, 2007.

[9] A. Moss. Printed Commonplace-Books and the Structuring of Renaissance Thought, Clarendon Press, Oxford, 1996.

[10] F. Bacon, Advancement of Learning, A. Johnston (ed.), Clarendon Press, Oxford, 1980.

[11] G.B. Marino. Le dicerie sacre, del Cav. Marino, presso Gio: Pietro Brigonci, in Venetia, 1675.

[12] J. Hagstrum. The Sister Arts. The Tradition of Literary Pictorialism and English Poetry from Dryden to Gray, Chicago and London, The University of Chicago Press, 1958.

[13] R.J. Clements. Picta Poesis: Literary and Humanistic Theory in Renaissance Emblem Books, Edizioni di Storia e Letteratura, Roma, 1960.

[14] R.W. Lee. Ut pictura poesis, Firenze, Sansoni, 1974.

[15] J. Elkins. Art history and images that are not art, The Art Bulletin Vol. 77, n. 4, 553-571, 1995.

[16] L. Louvel. Poetics of the Iconotext, edited by Karen Jacobs, Farnham and Burlington, Ashgate, 2011.

[17] W.J.T. Mitchell. Picture Theory: Essays on Verbal and Visual Representation, University of Chicago Press, Chicago, 1994.

[18] W.J.T. Mitchell. Iconology. Image, Text, Ideology, Chicago, University of Chicago Press, Chicago, 1986.

[19] D. N. Rodowick. Reading the Figural, or, Philosophy After the New Media, Duke University Press, Durham and London, 2001.

[20] P. Giovio. Ragionamento di Mons. Paolo Giovio sopra i motti, \& disegni d'arme, \& d'amore, che communemente chiamano Imprese, appresso Giordano Ziletti, all'insegna della Stella, In Venetia, 1556.

[21] R.L. Colie. The Resources of Kind: Genre-Theory in the Renaissance, edited by Barbara K. Lewalski, University of California Press, Berkeley and Los Angeles, 1973.

[22] M. Praz. Studies in Seventeenth-Century Imagery, $2^{\text {nd }}$ ed., 
Edizioni di Storia e Letteratura, Rome, 1964.

[23] E.H.Gombrich. Icones Symbolicae. The Visual Image in Neo-Platonic Thought, Journal of the Warburg and Courtauld Institutes 11, 163-192, 1948.

[24] A. Henkel, A. Schöne. Emblemata. Handbuch zur Sinnbildkunst des XVI. und XVII. Jahrhunderts, J. B. Metzler, Stuttgart, 1967.

[25] A.S.Q. Visser. Joannes Sambucus and the Learned Image: The Use of the Emblem in Late-Renaissance Humanism, Brill, Leiden, 2005.

[26] A.-E. Spica. Symbolique humaniste et emblématique. L'évolution et les genres (1580-1700), Honoré Champion Éditeur, Paris, 1996.

[27] G. Boehm, Die Wiederkehr der Bilder, in G. Boehm (Hrsg.), Was ist ein Bild?, Fink, München, 11-38, 1994.

[28] A. Adams, S. Rawles, A. Saunders. A Bibliography of French Emblem Books of the Sixteenth and Seventeenth Centuries, Volume 1, Droz, Genève, 1999.

[29] S. Gal, Linguistic Anthropology, in J.L. Mey, (ed.). Concise Encyclopedia of Pragmatics. Second Edition, Elsevier, Oxford, 519-533, 2009.

[30] W. Keane. Christian Moderns: Freedom and Fetish in the Mission Encounter, University of California Press, Berkeley, 2007.

[31] D. Russell. The Term "Emblème" in Sixteenth-Century France, Neophilologus Vol. 59, n. 3, 337-351, 1975.

[32] A.-E. Spica. Moralistes et emblématique, XVIIe siècle, Vol. 202, 169-180, 1999.

[33] B. Roukhomovsky. Lire les formes brèves, Nathan/VUEF, Paris, 2001.

[34] F. Picinelli. Mondo simbolico, o sia vniversità d'imprese scelte, spiegate, ed illvstrate ... con indici copiosissimi, per lo stampatore archiepiscopale, in Milano, 1653.

[35] M. Engelberts. Showing/Telling: The Social and Medial Context of a Malleable Notion, in V. Plesch, C. MacLeod and J. Baetens (eds.), Efficacité/Efficacy. How To Do Things With Words and Images?,Rodopi, Amsterdam and New York, 145-157, 2011.

[36] M. Fumaroli. L'Age de l'Eloquence, Droz, Genève, 1980.

[37] M. Leone. (In)efficacy of Words and Images in Sixteenth-Century Franciscan Missions in Mesoamerica: Semiotic Features and Cultural Consequences, in V. Plesch, C. MacLeod and J. Baetens (eds.), Efficacité/Efficacy. How To Do Things With Words and Images? Rodopi, Amsterdam and New York, 57-70, 2011.

[38] D. Borgogni. "Must I Needs Want Solidnesse Because by Metaphors I Speak?" Emblematics, Stylistics, Materiality, Linguistics and Literature Studies Vol. 3, n. 2, 75-82, 2015.

[39] K. Pinkus. Picturing Silence. Emblem, Language, Counter-Reformation, Materiality, Ann Arbor, The University of Michigan Press, 1996.

[40] P. Barocchi (a cura di), Scritti d'arte del Cinquecento. Tomo III, Ricciardi, Milano-Napoli, 1977.
[41] J. Crary. Techniques of the Observer. On Vision and Modernity in the Nineteenth Century, MIT Press, Cambridge, Mass. and London, 1990.

[42] J. Manning. Continental Emblem Books in Sixteenth-Century England: The Evidence of Sloane MS. 3794, Emblematica Vol. I, 1-11, 1986.

[43] J. Manning (ed.). The Emblems of Thomas Palmer. Two Hundred Poosees. Sloane MS 3794, AMS Press, New York, 1988.

[44] M. Bath. Speaking Pictures. English Emblem Books and Renaissance Culture, Longman, London and New York, 1994.

[45] A. Alciato. Andrea Andreae Alciati emblematum libellus, Excudebat Christianus Wechelut, sub scuto Basileiensi, in uico Iacobaeo, Parisiis, 1534.

[46] D. Wilson, D. Sperber. Outline of Relevance Theory, Links \& Letters Vol. 1, 85-106, 1994.

[47] H.P. Grice. Studies in the Way of Words, Harvard University Press, Cambridge, Mass. and London, 1989.

[48] C. Paradin. Devises Herö̈ques, Par M. Claude Paradin, Chanoyne de Beauieu, par Jean De Tournes, et Guil. Gazeau, A Lyon, 1551.

[49] G. Rollenhagen. Nucleus Emblematum Selectissimorum, E Musaeo coelatorio Crispiani Passaei, Prostant apud Io[n]ne[m] Iansoniu[m] bibliopola[m] Arnhemie[n]se[m], Coloniae 1611.

[50] C. Paradin. Devises Heroïques, Par M. Claude Paradin, Chanoyne de Beaujeu, par Ian De Tournes, et Guil. Gazeau, A Lion, 1557.

[51] G. Wither. A Collection of Emblemes, Ancient and Moderne, printed by A.M. for Henry Taunton, and are to be sold at his Shop in Saint Dunstanes Church-yard, London, 1635. 